\title{
Developing International Sukuk in East Asia: Implications from Hong Kong Sukuk
}

\author{
Michael Chak Sham Wong ${ }^{1}$, Waleed Irfan BHATTI ${ }^{2}$
}

Received: July 15, 2019 Revised: September 16, 2019 Accepted: September 24, 2019

\begin{abstract}
The purpose of this research is to review historical development of Islamic finance in individual East Asian economies, including China, Japan, South Korea and Hong Kong, and examine the success factors of the Hong Kong Sukuk issuances in 2014-2017. The research is a qualitative study applying case study method. It is found that the East Asian economies do play efforts to develop their Islamic capital markets although they have very limited size of Muslim population. Their progress on this development generally remains to be slow. The Hong Kong Sukuk is a breakthrough, carrying a total issuance value of US $\$ 3$ billion. The Sukuk issuances, treated as a kind of asset-backed securities with restrictions on financing purposes, are distributed to international investors by investment banks from Hong Kong, Middle East and Malaysia. Success factors of these issuances include involvement of an issuer with high credit quality, recognition by central bank for using the Sukuk in its discount facility for commercial banks, centralized clearing services for the Sukuk and global banking network for underwriting the Sukuk. The lessons from the Hong Kong Sukuk are good references for other economies to develop their regional Islamic capital markets and to integrate the markets into the global capital market.
\end{abstract}

Keywords : Islamic Finance, Sukuk, Capital Market, Financial Instrument, International Investment

JEL Classification Code : F21, G15, G24, O16

\section{Introduction}

Domestic capital market mainly helps fund users, including governmental organizations and corporations, to get long-term funds to support their business operation and expansion.

Central banks can also exercise their monetary policies by buying and selling government instruments in the market. International capital market plays a more complex role, facilitating international capital flows. International

1 First Author and Corresponding Author, Associate Professor of Finance, Department of Economics and Finance, College of Business, City University of Hong Kong, Hong Kong SAR, China. [Postal Address: Tat Chee Avenue, Kowloon, Hong Kong SAR, China] Email: efmcw103@cityu.edu.hk

2 Research Assistant, Department of Economics and Finance, College of Business, City University of Hong Kong, Hong Kong SAR, China. Email: waleed.irfan@outlook.com

(c) Copyright: Korean Distribution Science Association (KODISA)

This is an Open Access article distributed under the terms of the Creative Commons Attribution Non-Commercial License (http://Creativecommons.org/licenses/by-nc/4.0/) which permits unrestricted noncommercial use, distribution, and reproduction in any medium, provided the original work is properly cited. investors, including sovereign funds, pension funds, mutual funds and wealthy individuals, always look for suitable assets in the international capital market. Some of them invest in safer assets with lower returns. Some consider riskier assets with higher returns. Sizable organizations and corporations can issue equities, bonds and Sukuk in different world-leading financial centers and transfer those funds raised to their headquarters and regional offices. Through this process, they are able to shop for cheaper fund cost, diversify globally funding sources and achieve better tax benefits from some regions. A successful international Islamic capital market should play more or less the same role.

Many previous studies on Islamic finance focus mainly on its local issues in Islamic countries. Islamic supranational organizations occasionally conduct research on how to improve Islamic finance transactions among Islamic economies (COMCEC, 2018). Some previous research focus specific issues of Islamic products in Western markets (Abdullah, 2016). However, there is generally limited research on Islamic finance in East Asia. One reason is that 
East Asian countries are mainly secular states. Their governments are neutral to religions. Their societies accept a wide range of religious practices, in which Muslims simply account for a low percentage of their total population. Currently China (or China Mainland) has around 20 million Muslims but it remains to be tiny percentage as compared with its 1.4 billion population. Hong Kong has around 50,000 local Muslims and around 250,000 foreign workers with Islamic backgrounds. Muslim population in Taiwan, South Korea and Japan are very limited. There are a small number of Muslims working as foreign workers in Macau.

Despite of their less dominance of Islamic tradition, most East Asian economies have spent their efforts in promoting Islamic finance and Sukuk issuance for the last 10 years. Their motivations are straight-forward. First, they want to attract global investors and fund raisers, regardless of their cultural backgrounds, to make use of their well-established capital markets and financial institutions. Especially affluent investors from Gulf Cooperation Council (GCC) member states are their targets. Second, they want to help domestic and international investors get access to a new kind of assets which may be less associated with Europe and USA. Many East Asian investors gain unpleasant experience with the financial crisis in 2008 and European debt crisis in 20092012. USA and European assets may not be as safe as many investors originally think. Third, China's Belt-Road Initiative (BRI) triggers off discussion on a huge funding gap for Asian infrastructure projects. Many of these projects will take place in Islamic countries in Asia.

Naturally, Islamic finance pops up to be a solution. Among East Asian economies, Hong Kong is the more proactive in developing Sukuk market. The government starts planning Islamic capital market in 2007, amends its related laws in 2013, and originates three Sukuk issuances in 2014-2017. The Hong Kong Sukuk carries a total issuance value of US\$3 billion, distributed to international investors by investment banks from Hong Kong, Middle East and Malaysia. Success factors of these issuances include Hong Kong government as an issuer with high credit quality, recognition by Hong Kong Monetary Authority, the de facto central bank of Hong Kong, for using the Sukuk in its discount facility, centralized clearing services for the Sukuk and global banking network in Hong Kong for underwriting the Sukuk. The lessons from the Hong Kong Sukuk are good references for other economies to develop their regional Islamic capital markets and to integrate the markets into the global capital market.

This paper will proceed as follows. Section 2 of this paper summarizes what East Asia does in promoting Islamic finance. Section 3 highlights the characteristics of the Hong Kong Sukuk issuances and analyzes their success factors. Section 4 examines what can be learnt from the Hong Kong Sukuk on building international Sukuk market. Section 5 concludes the paper.

\section{Islamic Finance and Its Developments in East Asia}

Muslim population is around 1.8 billion in 2015 and will grow to 3 billion by 2060 (Lipka \& Hackett, 2017). Yet, the understanding of Shariah-compliant finance and its history has largely remained less popular in financial markets outside Islamic countries. The concept of Islamic Finance takes its roots from the religion itself, calling for a religious interpretation on conducting business and finances.

A primary rule of Shariah-compliant financing is the elimination of Usury (Ribaa). Ribaa has been condemned and mentioned within several verses of the Quran (Quran 2:275, Oxford World's Classic edition), the central religious text of Islam. In economic terms, both lenders and borrowers are forbidden from charging interest. This Shariah principle fundamentally deviates from operations of conventional finance, including commercial banking, central banking and bond markets. The Shariah aspect of financing also determines which business sectors to be financed. It essentially restricts banking and financing activities that involve business activities contrary to Islamic principles. Shariah-forbidding activities generally include arms, alcohol and tobacco (Alam, Gupta, \& Shanmugam, 2017).

To comply with Islamic principles, Islamic finance aims to provide funds to fund users with zero interest charge. A simple idea to eliminate the use of interest is to apply the principle of 'profit-sharing'. In this idea, a depositor maintains a saving account with an Islamic bank with zero interest earned. However, the depositor will share a fixed amount of the bank's profit. The shared profit is in fact similar to the interest income provided by a conventional bank. This profit-sharing principle is further applied to develop Sukuk, generally known as Islamic bond. Sukuk issuers transfer their profits from their regular business to a special purpose vehicle (SPV). Then the SPV distributes those amounts to Sukuk investors.

In 1990, Malaysia Shell MDS Sdn Bhd issues the first Sukuk in the world. In 2000, the government of Sudan issues the second Sukuk. Afterwards, many Islamic countries follow this practice. This makes Sukuk issuance growing steadily every year. More than $70 \%$ of Sukuk issuances are domestic Sukuk denominated in local currency. The first international Sukuk, denominated in US Dollar, was issued by Central Bank of Bahrain in 2001. In 2017, the total value of global Sukuk issuance was around US\$116.717 million, in which international Sukuk (mainly denominated in US Dollar) accounts for around US\$37.648 (IIFM, 2018). International Sukuk is mostly issued by central banks, governments, energy firms and utility companies from Islamic countries with high credit quality. Some international Sukuk are listed or traded on exchanges in Malaysia, Singapore, Dubai, Luxemburg, London and Belfast. Several non-Islamic economies, including UK, Singapore and Hong Kong, have their Sukuk issued. Their size is much smaller than the Sukuk by Islamic economies.

Islamic finance develops on principles of ethics. In 
recent years, there is a growing demand among investors towards ethical investment, with investment themes relating to Environmental Social Governance (ESG), "Green", social responsibility, sustainable development and social impact (UNDP, 2014). This new investment philosophy by and large allies with Shariah compliance. In 2017, Tadau Energy Sdn Bhd in Malaysia issues the first green Sukuk. In 2019, the government of Indonesia issues the second green Sukuk.

Malaysia is the largest international Sukuk market in the world, attracting Sukuk issuers and investors from various Islamic countries. Other Islamic economies, such as Turkey, Indonesia, Nigeria and United Arab Emirates, are also proactive in developing their international Sukuk market (COMCEC, 2018). In East Asia, due to its low percentage of Muslim population, there is limited number of Sukuk issuances. However, many East Asian economies spend efforts on promoting Islamic finance and Sukuk issuance. Their related efforts should not be ignored in the history of international Sukuk. Box 1 summarizes recent initiatives of China, Hong Kong, Taiwan and Japan on promoting Sukuk since 2014. Developments of Islamic finance in China, Hong Kong, Japan and South Korea are elaborated in following subsections.

Box 1: Initiatives in East Asian economies on developing Islamic finance (2014-2019)

China

- In 2017, China's ICBC underwrote both the bond and Sukuk of the government of Pakistan. Their total amount was around US $\$ 8$ billion.

- Asia Infrastructure Investment Bank (AlIB), after its establishment in 2015, consistently recommends Sukuk issuance to finance large infrastructure projects.

- Southwest Securities, a sizable securities firm in China Mainland, signed a deal with Qatar National Bank (QNB) and Qatar International Islamic Bank (QIIB) in 2015 to develop Islamic-compliance finance products in Qatar.

\section{Hong Kong}

- In 2017, Hong Kong Government issued its third USD-denominated Sukuk with a value of US\$1 billion and a maturity of 10 years. (HKMA, 2017)

- Hong Kong Government issued another five-year Sukuk at US\$1 billion in 2016. (HKMA, 2016)

- Hong Kong Government issued in 2015 a USD-denominated 5-year sovereign Sukuk at the value of US\$1 billion. The Sukuk was later listed on Hong Kong, Malaysia and Dubai exchanges. Investment banks from Hong Kong, the Middle East and Malaysia served as underwriters. (HKMA, 2015)

- Hong Kong amended its laws in 2014 to enable Hong Kong Monetary Authority to issue Sukuk. The new laws offer Sukuk a tax structure similar to bonds. (HKMA, 2014)

Taiwan

- In 2018, Saudi Arabian representatives visited Taiwan to explore of issuance Formosa Sukuk in Taiwan. Formosa bonds generally refer to off-shore bonds traded in Taipei.

Japan

- In early 2019, MUFJ issued Sukuk via its Malaysian branch and distributed it to Japanese domestic market. It is the first Japanese bank to market Sukuk in Japan domestic market.

\subsection{China}

Historically, there has been little demand within China for the development of Islamic finance. However, as the Chinese economy grows, its integration with the global financial markets gives rise to Islamic finance. Currently China maintains a very good relationship with the Muslim world in terms of increasing cross-border trade and direct investment. In 2015 there was agreement signed among Qatar International Islamic Bank QSC, QNB Capital and China's Southwest Securities. The agreement aimed to develop Shariah-compliant finance products in China, facilitating GCC investors in invest in China. Asian Infrastructure Investment Bank (AIIB) headquartered in Beijing has taken a lead in making efforts towards the establishment of outbound Islamic financing frameworks. In 2017, ICBC, a leading China bank, underwrote the bond and
Sukuk issued by the government of Pakistan.

History of Islamic finance in China can be traced back to 1987. At that time, with demand from local Chinese Muslim businessmen, its first Shariah-compliant bank, known Hezhou Islamic Financing Company, opened. This company obtained support by the local government and the Central Bank, offering Islamic banking services. However, as China's economy continued to develop at a rapid pace, the bank struggled to compete and went out of business in 2007.

In Ningxia, a province of China, Muslims make up to $35 \%$ of its local population. In 2009, China's central bank supported regional banks in Ningxia to roll out Islamic financial services. In 2015, China proposed a plan to establish an Islamic financial center in the capital of Ningxia, aiming to foster greater cooperation between China and the Middle East. Yet, this plan does not have much progress.

To attract Middle-East funds to China market, the 
country allowed Shariah-compliant funds to operate in the mid-2000s. For instance, Bahraini Shamil Bank established a $\$ 100$ million Shamil China Reality Mudarabah (Islamic Contract). The Mudarabah was the first Islamic property endowment fund investing in China real estates. The asset management arm of Deutsche Bank, DWS Investments, launched its first Shariah-compliant mutual fund known as DWS Noor China Equity Fund. CIMB launched a CIMB Greater China Equity Fund. In late 2000s, China joined the Islamic Financial Services Board (IFSB), an international body setting standards and offering guidance for Islamic banking and finance regulatory and supervisory agencies. There was a proposal between IFSB and China to study legal amendments to facilitate the development of Islamic finance in China. So far, there is very little progress.

There are multiple reasons for China to develop Islamic capital market amid China reaches a new sphere in its economic development (Rakhmat, 2019). International capitals from Islamic countries are helpful to China in terms of its economic growth. To attract Islamic capitals, there should be Shariah-compliant financial products relating China domestic economic activities. China currently maintains a huge amount of foreign reserve. Sukuk issued by Islamic governments helps China reduce its heavy exposure to USA and European government bonds. China continues to increase its outbound direct investment under the BRI, in which many projects go to Islamic countries. China project owners can diversify their funding sources via Sukuk issuance, bond issuance and bank loans. Despite of many benefits of fostering Islamic finance for China, there is not much progress on such market development within China Mainland. It is probably due to political consideration of the China government.

\subsection{Hong Kong}

Hong Kong, a special administrative region of China, has long stood as the global financial center and as a gateway to the China economy. The city hosts third largest stock exchange in Asia, which ranks the fourth in the world in terms of market capitalization. The city houses around 200 international banks from various parts of the world. The city has already taken a lead among North Asian economies in establishing an Islamic capital markets center in the region. However, there is still a long way for the city to go before a system is in place for the market to develop, while tapping onto the opportunities of the one-belt-one-road initiative.

Islamic finance is a fairly recent addition to the financial ecosystem of Hong Kong. It gathers global interest with the city's inaugural Sukuk offering in 2014. In 2007, Hong Kong started to develop frameworks for the development of Islamic finance. Related amendments on laws took place in 2013, providing a legitimate framework for Sukuk issuance in the city. In 2014, the Hong Kong government issued its first Sukuk under the Government Bond Programme (HKMA, 2014). This was a Sukuk with 5-year tenor and denominated in US Dollar. It was the world-first Sukuk assigned with AAA rating. The Sukuk was advertised through global roadshows in the major financial centers in the world and the middle-east. The issuance was largely a success with orders exceeding US $\$ 4.7$ billion dollars for the US $\$ 1$ billion issuance, thus an oversubscription rate of 4.7 . The issuance was allocated to over 120 institutional investors throughout Asia, the Middle East, as well as Europe and North America. This set a benchmark for developed economies for Sukuk issuance. The Sukuk adopted an Ijarah structure, a form of Sukuk built around leasing of an underlying asset.

The Hong Kong government continued it with 2 more offerings. In 2015, the government issued another US\$1 billion 5-year tenor Sukuk, but using a Wakalah structure, a form of Sukuk akin to an agency agreement, making it the first to be issued by a AAA-rated government (HKMA, 2015). Though this time, only orders of US $\$ 2$ billion were attracted. In 2017, the government issued a 10-year Wakalah Sukuk at the value of US\$1 billion (HKMA, 2017). This issuance attracted an oversubscription rate of 1.72. Overall speaking, the Hong Kong government successfully issue Sukuk, a product less familiar in East Asian capital markets, and create its Sukuk yield curve.

Although Hong Kong made attempts in developing its own Islamic ecosystem, there has not been much development since 2017 (Caudevilla, 2018). In 2018, international Sukuk issuance generally slowed down because of USA-China trade negotiation and tension of the Gulf area.

\subsection{Japan and South Korea}

In 2008, Japan revised its banking law to include a concept of cash transaction based on the religious doctrine. This revision effectively recognized Islamic finance and aimed to attract international capitals from the Middle East. In 2011, the country amended its asset securitization law, considering Sukuk as a type of fixed income securities under specific purpose trust (SPT). After this amendment, Sukuk issued by foreign entities became eligible to be listed on Tokyo exchange. However, there has been no record of Sukuk issuance in Japan. In 2014-2017, a number of Japanese companies, namely Aeon Credit Service, UMW Toyota Capital, Nomura Holdings, and MUFJ, successfully issued their Sukuk in Malaysia (Ogino, 2018). In 2019, MUFJ, one the largest Japanese banking groups, issued Sukuk via its Malaysia branch and marketed the Sukuk to the domestic market of Japan.

In Korea, progress has been limited (Chang, 2015). There have been long attempts to develop the Islamic finance sector within the country. In 2008, there was a proposal to make amendments to the tax laws in Korea, granting Sukuk exemption from income tax and corporation tax. This aimed to give Sukuk the same treatment similar to bonds denominated in foreign currency. The amendment was however cancelled without being presented to the 
country's legislators. Briefly, there is only a microscopic market present for Islamic finance within Korea, largely due to inadequate regulation in place to facilitate development of Islamic finance.

\subsection{General Issues of Sukuk Issuance in East Asia}

One issue among East Asian economies on promoting Islamic finance is regulation. East Asian governments tend to be neutral to religions. Their financial regulation and financial laws would not have any section on Shariah compliance. It usually takes some time for East Asian economies to amend their laws and regulations to accommodate Sukuk issuance. For East Asian economies, Sukuk is simply regarded as a type of asset-backed securities with specific restrictions on their financing purposes. With limited knowledge about Islamic tradition, East Asian investors generally do not too much about Sukuk regarding Shariah compliance. However, they generally understand that Sukuk is an asset class welcome by Islamic communities.

Another issue is limited domestic demand for Sukuk. Investors from this region can easily get access to wide range of financial assets in advanced and emerging economies via their local banks, financial brokers and fund houses. Currently Sukuk issuance is mostly limited to issuers from Islamic countries. The market of Sukuk is relatively small as compared with the market of conventional bonds in the world. East Asian economies in fact have already developed their sizable bond market for the past 20 years. The size of their bond market is much larger than that of all Sukuk in the world. Table 1 displays the statistics of all Sukuk issuance as compared with bond issuance of selected East Asian economies in 2017.

Table 1: All Sukuk issuance versus East Asian Bond Issuance (2017)

\begin{tabular}{|l|c|c|}
\hline Economy & Total(USD billions) & \% of All Sukuk \\
\hline China & 710.77 & $16.42 \%$ \\
\hline Japan & 405.88 & $28.76 \%$ \\
\hline South Korea & 170.51 & $68.45 \%$ \\
\hline Hong Kong & 113.19 & $103.11 \%$ \\
\hline All Sukuk & 116.72 & $100.00 \%$ \\
\hline
\end{tabular}

NB: Data for the selected Asian economies come from Asiabondonline (a portal of Asia Development Bank). Data for "Global Sukuk", including both domestic and international Sukuk, comes from IIFM Annual Report (April 2018) of International Islamic Financial Market.

All Sukuk issuance is around $17 \%$ of bond issuance in China, 29\% in Japan and 69\% in South Korea. The size of all Sukuk issuance is just close to that of bond issuance in Hong Kong. To shift their attention from conventional bond to Sukuk, there should be strong rationale to support their risk-return consideration. Issuer names, credit ratings, expected returns, purposes of financing, benefits on diversification, currency denomination, settlement locations, custody locations, and marketability are important factors
East Asian investors generally consider.

The Sukuk issuances of Hong Kong government in 2014-2017 seem to be a major breakthrough in East Asia. Its total deal size is around US\$3 billion. The Hong Kong Sukuk is successfully distributed to international investors from Asia, Europe and North America. The following section offers more discussion on why these deals turn out to be successful.

\section{The Case of Hong Kong Sukuk}

The Hong Kong Sukuk, issued by the Hong Kong government, is generally considered to be a success in developing Islamic finance in East Asia. The three Hong Kong Sukuk issuances engage investment banks from Hong Kong, Middle East and Malaysia. Lead managers and book runners include HSBC, Standard Chartered Bank, CIMB, National Bank of Abu Dhabi, BOCOM (Hong Kong), Maybank, Hong Leong Islamic Bank and NCB Capital. The first 2 issuances are 5-year tenor and the last deal is 10-year tenor. Each of the issuance is US\$1 billion in notional amount. For the last Sukuk issuance, Hong Kong Monetary Authority announces in 2017:

"[the 10-year Sukuk] attracted interest from a diverse group of conventional and Islamic investors. Orders were received from over 88 global institutional investors, and $57 \%$ of the Sukuk was distributed to Asia, $25 \%$ to the Middle East and $18 \%$ to Europe. By investor type, 53\% was distributed to banks, $36 \%$ to fund managers, private banks and insurance companies, and $11 \%$ to sovereign wealth funds, central banks and supranationals" (HKMA, 2017)

If similar Sukuk issuance continued annually and extended to other East Asian issuers, international Sukuk market would develop rapidly. It is worthwhile to examine the success factors for this Hong Kong Sukuk. These factors are identified below.

\subsection{Availability of High-quality Issuers}

Hong Kong government is one of the well-known bond issuers in East Asia. These Sukuk deals simply change a structure of fixed income securities from bond to Sukuk, without any change in credit quality of Hong Kong. These Sukuk deals are assigned AA to AAA by global credit ratings agencies. Expected return from the Sukuk is close to the bond yield of Hong Kong government bonds. In the international capital market, fixed income securities of high credit quality always have strong demand. Conservative investors always prefer safe assets because of their low liquidity risk and low investment risk. Fixed income securities with Grade AA or better may offer a return at 3\% to $4 \%$. This appears to be less attractive in term of their absolute return. However, this level of return can be 
lucrative profit for an investor with average funding cost at $1 \%$ to $2 \%$ only.

Many commercial banks and insurance companies do in fact have low funding cost, thus having strong interest in safe assets. Also, Basel III, the global banking regulation, assigns low capital requirements to A-rated to AAA-rated debt instruments. This motivates banks from advanced economies to invest in high-quality conventional bonds and Sukuk. High-quality assets with strong credit ratings tend to be marketable in the international capital market, being considered to be low in liquidity risk. Under the Liquidity Coverage Ratio (LCR) of Basel III, government and corporate bonds at Grade AA and or better are recognized as High-Quality Liquid Asset (HQLA). This LCR requirement motivates commercial banks to accumulate HQLA to improve their liquidity ratios.

If a Sukuk is issued by an AA-rated entity, which may include a supranational, government, financial institution or corporation, it will be well-accepted by global institutional investors. Sukuk market development requires the presence of high-quality Sukuk issuers. East Asian economies generally have strong sovereign ratings. For instance, South Korea, Taiwan and Hong Kong usually get Grade AA. China and Japan mostly have Grade A or better. Their ratings are as good as many GCC member states. In addition, many multinational companies and state-supported enterprises in East Asia have their bond ratings at $\mathrm{A}$ or better. To successfully develop international Sukuk market, Islamic banks should identify high-quality bond issuers in East Asia and help them issue Sukuk.

\subsection{Collaboration between Islamic and East Asian Banks}

Underwriting of the Hong Kong Sukuk is collaborated by both Islamic and non-Islamic banks from different financial centers of the world. The banks successfully reach out to a wide range of institutional investors. These institutional investors include sovereign funds, commercial banks, investment banks, fund houses and insurance companies from different countries. In principle, Sukuk should be more marketable than bond because it is suitable for investors from different cultural backgrounds. In practice, Sukuk is mostly restricted to Islamic economies. To make Sukuk better known to East Asia, Islamic banks may need to rebrand Sukuk to be a universally-accepted financing tool. They can work out standardized templates with East Asian banks to support Sukuk issuance. These templates cover a generally-accepted Sukuk structure, a whitelist of business activities that Sukuk can finance, underwriters to be involved and etc. Preferably these East Asian Sukuk issuance templates involve less religious terms and apply wordings generally understood by global investors.

\subsection{High Liquidity and Marketability}

Most conventional bonds are less actively-traded in the secondary market. In other words, they tend to have low market liquidity. However, some bonds are considered as highly liquid assets because they are eligible assets in the repurchase agreement (repo) market. The Hong Kong Sukuk instruments are recognized by HKMA for its discount window facility, which allows commercial banks in Hong Kong to get short-term funds from HKMA, the de facto central bank in Hong Kong, via a repo. A discount window facility is extremely important for commercial banks to deal with their daily liquidity needs. In general, a repo allows a fund user to sell an eligible asset to a fund provider and agrees to buy back the asset at a slightly higher price. In Western finance, a repo is similar to a collateralized loan. In recent years, central banks in Malaysia, Indonesia and Dubai have their repo systems established for Islamic banks. A central bank generally considers government bonds and other fixed-income securities with strong credit ratings as eligible assets for repo transactions. In addition, in some financial centers, commercial banks develop their own repo market for soliciting short-term funds from their peers. Including Sukuk into a repo system is essential to make Sukuk to be liquid and marketable securities and to make it to have string global demand. Islamic banks should maintain dialogue with central banks and interbank market associations in East Asia on including high-quality Sukuk into their repo systems.

\subsection{Needs for Global Diversification}

Islamic investors show strong interest in the Hong Kong government Sukuk because it helps them diversify their investment risk globally and lowers their liquidity risk. Currently Sukuk is mostly issued by issuers from emerging Asian countries and GCC members. Their economic performance and repayment risk are strongly associated with energy and commodity prices. Hong Kong has different economic setting that repayment risk of Hong Kong Sukuk tends to be less correlated with other existing Sukuk issuers. East Asian economies have a better mix of business sectors, including agricultural production, manufacturing, technology, pharmaceuticals, banking services, tourism and etc. Including Sukuk issuers from East Asia would make international Sukuk market more appealing to global investors for their needs of risk diversification.

\subsection{Low Settlement and Custody Risk}

An investor of the Hong Kong Sukuk can store the securities at the Central Moneymarket Unit (CMU) of the Hong Kong Monetary Authority. The CMU is like a central settlement and clearing system for fixed income securities traded in the Hong Kong interbank market. Currently it 
stores fixed-income securities of local and international issuers, including governmental institutions (Hong Kong, China, Canada, Australia, Japan and etc....), supranationals (IMF, World Bank, Asia Development Bank....), banks and corporations. International investors always consider settlement risk and custodian risk as two important factors to enter into a market. In simple words, their concerns are all about where to pay cash, where to receive securities, where to store the securities for sale, and where to keep the cash after sale.

Currently international bond investors mostly do posttrade settlement at major financial centers, such as New York, London, Zurich, Tokyo, Singapore and Hong Kong. The reason is that these financial centers have less restriction on international capital flows, lower country risk for cross-border financial transactions, strong capacity to deal with multiple-currency transactions, and strong networks with regional and global banks. International Sukuk currently has most of their post-trade settlement done in Malaysia, which is still an emerging economy. To make Sukuk more user-friendly for international investors, Islamic banks should develop Sukuk settlement in various leading financial centers and work closely with central clearing agencies of these centers. Trading today can take place globally via internet platforms but post-trade settlement remains to be transactions at clearly specified locations. These locations must allow buyers and sellers to feel safe.

It seems that Sukuk issuance in an advanced economy, like Hong Kong, has better advantages to reach out to international investors from both Islamic and non-Islamic countries. Currently Malaysia is the largest Sukuk market but it mostly serves investors and issuers from Muslimmajority countries. An international capital market is in fact comprised of a number of world-leading financial centers in the world. These centers house regional and international banks, which support their clients to shop for suitable assets and transfer funds globally. An international Sukuk market should include more than one financial center for issuance, trading and settlement. In Asia, both Hong Kong and Singapore house many regional and international banks. In Europe, both London and Zurich play the same role for international transactions. Islamic banks should explore how to further incorporate Sukuk issuance in these international centers.

\section{Discussion and Recommendation}

Developing Sukuk market in East Asia seems to be very challenging because of its limited Muslim population in the region. However, it is clear that East Asian economies are open in integrating Islamic finance into their current financial systems. They have tried their efforts in Sukuk issuance, amending their laws for Islamic banking and Sukuk issuance, and meeting banks from Islamic economies for future collaboration. One of their general concerns is that East Asian governments do not want to link Sukuk too much with religions or a specific religion because they tend to be neutral to religions. With a hope to build stronger connection with Islamic economies, they are more inclined to treat Sukuk as an asset type for global investment and international financing.

To make Islamic finance popular in East Asia or nonIslamic regions, the experience of Malaysia provides good reference. Malaysia stands out as a champion for the integration of Islamic Finance into conventional finance. There are a number of factors allowing Malaysia to stand out (Allawala, 2018). Malaysia has more than 30\% nonMuslim population. Hence, Malaysian financial products, including Sukuk subscription, tend to be inclusive. This means, they do not restrict their clientele to Muslims only. In addition, regulatory bodies in Malaysia, Bank Negara Malaysia and Securities Commission, set adequate rules in bringing consistency in the markets (DeLorenzo, 2011). For instance, the Securities Commission set up an Islamic capital market department to guide the development of Sukuk market and set up the Shariah Advisory Council (SAC) to advise on matters related to Shariah compliance. With the support of Bank Negara Malaysia, Islamic banks establish the Association of Islamic Banking and Financial Institutions in 1995 to promote Islamic finance.

For Sukuk market in East Asia, Islamic banks should work out specific templates, in collaboration with their domestic banks, suitable for Sukuk issuance in East Asia. The templates should comply with local laws in East Asia and incorporate Shariah principles. These templates can be applied to issuers from both East Asia and Islamic world for their Sukuk issuance in East Asia. Currently Hong Kong provides a well-developed framework and track records for Sukuk issuance. In Hong Kong, there are licensed banks coming from Islamic countries, such as United Arab Emirates, Qatar, Indonesia, Malaysia and Pakistan. Many global banks operating in Hong Kong, such as HSBC, Standard Chartered, Bank of China and DBS, have their branch offices in different Islamic countries. The banking network in Hong Kong will be helpful to Sukuk issuance and underwriting. The Hong Kong Sukuk provides insights on developing international Sukuk market in East Asia. The success factors on the deals include:

Arranging Sukuk issuance by high-quality bond issuers from East Asia.

Making Sukuk to be eligible assets for repo in discount window and/or interbank market in East Asia.

$\bigcirc$ Arranging clearing agencies in East Asia to support Sukuk custody and settlement.

$\bigcirc$ Allying Islamic banks and East Asian banks on Sukuk issuance and global underwriting.

In brief, high credit quality, recognition by central banks in discount facility, central clearing mechanism and global network for underwriting are success factors on international 
Sukuk issuance. Developing Sukuk issuance in East Asia will benefit Islamic economies eventually. With increased number of Sukuk issuance and stronger interest in this asset type, Islamic governments and corporations can raise funds conveniently from affluent East Asia economies, through their sovereign wealth funds, pension funds, mutual funds and wealthy individuals. Also, Islamic investors will easily invest in Sukuk issued by East Asian issuers in order to globally diversify their investment risk.

\section{Conclusion}

This paper has discussed the developments of Islamic finance and Sukuk development in East Asia. Both China and Japan are among the top three economies in the world in terms of nominal GDP. Japan, South Korea and Hong Kong belong to affluent economies in terms of their GDP per capita. These economies generally have low percentage of Muslim population. However, many of them have strong intention to develop Islamic finance.

To support Islamic finance, some East Asian governments amend their local laws to facilitate Sukuk issuance. The Hong Kong Sukuk, issued by the Hong Kong government in 2014-2017, is a breakthrough in East Asia on developing Islamic finance. Its deal size involves a total value of US\$ 3 billion. The Sukuk is distributed to international investors with the help of investment banks from Hong Kong, Middle East and Malaysia. The issuance are treated as a category of asset-backed securities with restrictions on financing purposes. Both green bonds and Sukuk can fall into such a category. If these issuances repeat in East Asia, the size of international Sukuk market will be able to grow rapidly.

There are several success factors that make the Hong Kong Sukuk well-received in the global market. These factors include involvement of issuers with high credit quality, recognition by central banks for using Sukuk in their discount facility, centralized clearing services for the Sukuk and global banking network for underwriting the Sukuk. These lessons can be good references for other economies to develop their regional Islamic capital markets.

This study has a limitation that it focuses mainly on historical developments in the past 10 years. Future developments on Sukuk market may be different if there is further collaboration among Islamic banks and East Asian banks. However, the study documents the status quo of Sukuk market in East Asia and helps Islamic banks formulate better business strategies in East Asia.

So far there is limited study on Islamic finance in East Asia. The significance of this research is to highlight the intentions of East Asian economies to develop Islamic finance, their domestic efforts in supporting Islamic finance, their challenges in developing Islamic finance, and the success factors contributing to development of Islamic finance in East Asia.

\section{Reference}

Abdullah, A. (2016). Examining US approvals of Islamic financing products and the Islamic theory of lawful profit. International Journal of Islamic and Middle Eastern Finance and Management, 9(4), 532-550.

Alam, N., Gupta, L., \& Shanmugam, B. (2017). Islamic finance: A practical perspective. New York, NY: Springer.

Allawala, A. (2018, April 27). Five reasons why Malaysia's Islamic banking sector is taking off. Standard Chartered Bank. Retrieved September 17, 2019, from https://www.sc.com/en/trade-beyond-borders/fivereasons-why-malaysias-islamic-banking-sector-istaking-off

Caudevilla, O. (2018, December 14). HK should aim to be a hub for Islamic finance. China Daily. Retrieved September 17, 2019, from http://www.chinadaily.com.cn/hkedition/201812/14/content_37405498.htm

Chang, Y. (2015, July 15). Islamic finance in Korea: Is the timing right for it? Eurekahedge. Retrieved September 17, 2019, from http://www.eurekahedge.com/Research/News/1428/Isla mic_Finance_News-

Islamic_Finance_in_Korea_Is_the_Timing_Right_for_It COMCEC. (2018, February). The role of Sukuk in Islamic capital markets. The Standing Committee on Economic and Commercial Cooperation of the Organization of Islamic Cooperation. Retrieved September 17, 2019, from http://www.sbb.gov.tr/wpcontent/uploads/2018/11/The_Role_of_Sukuk_in_Islami c_Capital_Markets.pdf

DeLorenzo, A. U. (2011). Building up an Islamic capital market: The Malaysian example. In K. Hassan, \& M. Mahlknecht (Eds.). Islamic capital markets: Products and strategies (pp. 221-234). New York, NY: Wiley

HKMA. (2014). Press release: HKSAR government's inaugural Sukuk offering. Hong Kong Monetary Authority. Retrieved September 17, 2019, from https://www.hkma.gov.hk/eng/key-information/pressreleases/2014/20140911-3.shtml

HKMA. (2015). Press release: HKSAR government's Sukuk offering. Hong Kong Monetary Authority. Retrieved September 17, 2019, from https://www.info.gov.hk/gia/general/201505/28/P201505 271108.htm

HKMA. (2017). Press release: HKSAR government's Sukuk offering. Hong Kong Monetary Authority. Retrieved September 17, 2019, from https://www.hkma.gov.hk/eng/key-information/pressreleases/2017/20170222-3.shtml

IIFM. (2018). IIFM Sukuk reports: A comprehensive study of the global Sukuk market (7th Edition). International Islamic Financial Market. Retrieved September 17, 2019, from 
http://www.iifm.net/system/files/private/en/IIFM\%20Su kuk\%20Report\%20\%287th\%20Edition\%29_0.pdf

Lipka, M., \& Hackett, C. (2017). Why Muslims are the world's fastest growing religious group. Pew Research Center. Retrieved September 17, 2019, from https://www.pewresearch.org/fact-tank/2017/04/06/whymuslims-are-the-worlds-fastest-growing-religious-group

Ogino, Y. (2018). Developments of Sukuk (Islamic bond) market and challenges of Japanese market. Newsletter, Institute of International Monetary Affairs. Retrieved September 17, 2019, from https://www.iima.or.jp/en/docs/newsletter/2018/NL2018
No_2_e.pdf

Rakhmat, M. Z. (2019). The rise of Islamic finance on China's belt and road. The Diplomat, February. Retrieved September 17, 2019, from https://thediplomat.com/2019/02/the-rise-of-islamicfinance-on-chinas-belt-and-road

UNDP. (2014). Islamic finance and impact investing. United Nations Development Programme. Retrieved September 17 , 2019 , from https://www.undp.org/content/dam/istanbul/docs/Islamic _Finance_Impact.pdf 